\title{
Efforts to Increase Student Academic Achievement Through Knowledge Sharing
}

\author{
Suhana Suhana ${ }^{1, *}$, Anwar Mansyur $^{2}$, Lutfika Rachmawati $^{3}$ \\ ${ }^{1,2,3}$ Department of Management, Universitas Stikubank, Semarang, Indonesia \\ suhana@edu.unisbank.ac.id
}

\begin{abstract}
This paper aims to gather empirical evidence regarding the effect of trust, benevolence, and self-efficacy for knowledge sharing on knowledge sharing. Additionally, the study seeks empirical evidence regarding the influence of knowledge sharing on students' academic achievement. The research population consists of currently enrolled students from private universities in Semarang, Central Java, Indonesia. There are 223 respondents in the sample. Non-probability sampling is employed in this study. The data collection technique was carried out utilizing the Structural Equation Model-WarpPLS. According to the hypothesis test, the variables trust, altruism, and knowledge sharing self-efficacy all positively affect knowledge sharing sharing. The obtained results imply that knowledge sharing has a beneficial effect on students' academic achievement. The study has consequences for both theory and practice. Additionally, the paper makes research recommendations.
\end{abstract}

Keywords: student academic achievement, knowledge sharing, benevolence

\section{INTRODUCTION}

Numerous internet users have been interested in social networking sites. These websites have been ingrained in the daily lives of multiple groups of people. Students are a subset of the active internet user community. Twitter and Facebook are two popular social networking sites students utilize [1]. Among the organizations that gain significantly from the growth of this social network are higher education institutions. According to what was stated [2], social networks are a tool utilized by lecturers and students to facilitate education. A growing number of internet users collaborate on social media to gain the necessary knowledge. Numerous issues can be resolved by gaining access to knowledge via social networks [3]. [4] asserted that informal education occurs through social networks. As a result, sharing knowledge via social media can help boost individual knowledge. In higher education, knowledge sharing can help students enhance their academic performance. This vein is consistent with previous findings [5] and [6], indicating that information sharing via social networks significantly impacts student academic achievement. Academic performance can be improved by increasing knowledge sharing activities among students using social media platforms. The study focuses on various characteristics that are projected to promote knowledge sharing. According to a review of prior research, it is known that the variables of trust, benevolence and KS self-efficacy can all contribute to an increase in knowledge sharing activities [5] [6] [7].
In organizational research, trust is defined as a set of beliefs about people that encompasses attributes such as honesty, compassion, emotion, benevolence, and capability [8]. Meanwhile, as defined by [9], trust refers to integrity. In knowledge exchange, trust is critical and necessary for people to engage in online conversations [10]-[11]. Along with trust, it is considered that benevolence affects knowledge sharing. Benevolence is described as the willingness to assist others without expecting anything in exchange. According to [12], charity affects the desire to share information. Benevolence will motivate a person to give his knowledge. Along with trust and benevolence, it is projected that knowledge sharing will be influenced by KS self-efficacy. In [13], authors discovered that individuals with the potential to have pleasurable social influence might utilize online social networks to develop, expand, and sustain relationships with other online users. Self-efficacious individuals go above and beyond to interact with and then share information with others.

The goal of this study was to evaluate and assess the effects of trust, benevolence and KS self-efficacy on knowledge sharing and their impact on students' academic achievement. The study is a follow-up to [5]. The study aims to address a research gap by broadening the scope of the research object, population, and sample for generalization. 


\section{LITERATURE REVIEW AND HYPOTHESES DEVELOPMENT}

Trust is a significant factor in motivating someone to disclose information on the web [14]. In [15], authors discovered that the more trust between individuals, the more ready individuals are to share resources with others. Trust plays a critical role in information sharing, as evidenced by the available research [16]. The increased trust of online users will result in increased knowledge exchange. If online media users are concerned about other users' actions, such as the misuse of shared knowledge, they will refrain from sharing their expertise via the internet. The first hypothesis follows from the description above: H1. Trust has a beneficial effect on students' knowledge sharing. According to [17], knowledge workers share knowledge because of a sense of fulfilment gained from assisting others. Thus, benevolence is a significant influence on online user behaviour regarding social networks. In other words, benevolence is a factor affecting knowledge sharing. Assumedly, $\mathrm{H} 2$ benevolence has a beneficial effect on students' knowledge sharing. Numerous studies explored the effect of knowledge sharing self-efficacy on knowledge sharing intention. According to [18], self-efficacy is a critical component of self-motivation to share information. [19] examined KS self-efficacy as an intrinsic benefit factor and compared it to other variables to determine its effect on knowledge sharing behaviour. The findings indicate that self-efficacy has a beneficial impact on knowledge sharing when an electronic knowledge repository is used. Because knowledge sharing is extensively practised through the internet as a means of communication, an individual's internet self-efficacy is critical for promoting knowledge sharing behaviour [20]. According to the above description, H3. KS selfefficacy has a beneficial effect on student knowledge sharing. According to [21], those who shared their knowledge fared better in group assignments. Another study, whose findings corroborate the preceding, found that social networks can help students enhance their academic performance when lecturers incorporate social media into their teaching methods [22]. Improved scholarly communication has been shown to benefit classroom discussions and student involvement with colleagues [23]. Online social networks can allow more effective interpersonal assistance, collaborative information sharing, and knowledge accumulation [24]. As a result of the above description, $\mathrm{H} 4$ indicates that knowledge sharing has a beneficial effect on student academic achievement.

\section{RESEARCH METHOD}

The research population consists of students at private universities in Semarang. Non-probability sampling is used in the sampling procedure. Academic achievement was assessed using a questionnaire adapted from [25] and [26]. The concept of knowledge sharing was derived from [27] and [28]. The trust concepts were adapted from [16] and [9]. While [27] developed a questionnaire to assess benevolence. The researchers employed a questionnaire to assess knowledge sharing self-efficacy [29]. The study's data will be handled using Structural Equation ModelingPartial Least Squares (SEM-PLS) with the WarpPLS tool.

\section{RESULTS AND DISCUSSION}

The results of hypotheses testing on the inner model can be seen in Table 1

\begin{tabular}{|c|c|c|c|c|}
\hline $\begin{array}{l}\text { Predictor } \\
\text { Variable }\end{array}$ & $\begin{array}{l}\text { Response } \\
\text { Variable }\end{array}$ & $\begin{array}{c}\text { Path } \\
\text { Coeffici } \\
\text { ent }\end{array}$ & $\begin{array}{c}\mathrm{p}- \\
\text { value }\end{array}$ & $\begin{array}{c}\text { Remar } \\
\text { ks }\end{array}$ \\
\hline Trust & & 0.320 & $\begin{array}{c}<0.0 \\
01\end{array}$ & $\begin{array}{c}\text { H1 } \\
\text { accept } \\
\text { ed }\end{array}$ \\
\hline Altruism & $\begin{array}{l}\text { Knowled } \\
\text { ge Share }\end{array}$ & 0.142 & $\begin{array}{c}0.01 \\
5\end{array}$ & $\begin{array}{c}\mathrm{H} 2 \\
\text { accept } \\
\text { ed }\end{array}$ \\
\hline $\begin{array}{c}\text { Self- } \\
\text { Efficacy }\end{array}$ & & 0.225 & $\begin{array}{c}<0.0 \\
01\end{array}$ & $\begin{array}{c}\text { H3 } \\
\text { accept } \\
\text { ed }\end{array}$ \\
\hline $\begin{array}{c}\text { Knowled } \\
\text { ge Share }\end{array}$ & $\begin{array}{c}\text { Performa } \\
\text { nce }\end{array}$ & 0.427 & $\begin{array}{c}<0.0 \\
01\end{array}$ & $\begin{array}{c}\mathrm{H} 4 \\
\text { accept } \\
\text { ed } \\
\end{array}$ \\
\hline
\end{tabular}

Table 1. Model Fit and Quality Indices Results

\subsection{The effect of trust on knowledge sharing}

The research demonstrates that trust has a beneficial influence on knowledge sharing. Respondents believe that trust is a necessary component of knowledge sharing. Building trust among people is critical in this situation. Through ongoing encounters, they can establish trust. The finding is consistent with those of prior studies. In [7], authors researched methods that promote student participation and performance in knowledge sharing. The obtained results suggest that the trust variable has a beneficial effect on knowledge sharing. Another research finding supporting this conclusion is that trust is a critical component of creating healthy interpersonal connections [29]. Additionally, this circumstance will motivate students to share their knowledge. 


\subsection{The influence of benevolence on knowledge sharing}

According to the research findings, benevolence has a beneficial effect on knowledge sharing. According to the results, it is critical to develop student benevolenve to share knowledge via social media. Benevolence can be increased in an organizational context by emphasizing being helpful to colleagues. By strengthening these beliefs, they can be standardized and eventually transformed into cultural values that guide the behavior of organization members.

The outcomes of this study corroborate other prior studies. [5] investigated the influence of knowledge sharing on students' academic achievement. The data indicate that charity has a beneficial effect on knowledge sharing. According to this study, highintensity communication amongst students impacts knowledge sharing behavior. This conduct indirectly promotes the establishment of intrinsic pleasure [30]. They engage in knowledge sharing because they believe that assisting colleagues with challenges is enjoyable. They are at ease while performing [31].

\subsection{Effect of KS self-efficacy on knowledge sharing}

The findings indicate that knowledge sharing self-efficacy has a beneficial effect on knowledge sharing. KS self-efficacy refers to a person's confidence in his ability to accomplish something. He believes he can share knowledge with his colleagues in this context. He also has faith in his ability to inform his college buddies about fascinating and valuable things via social media. The findings of this study corroborate some earlier studies. The study's findings [5] indicate that KS self-efficacy is critical in shaping knowledge sharing behavior. The findings suggest that they share knowledge because they believe in their communication capacity. Students who have a strong belief in their ability to impart knowledge will be more motivated to do so with their peers. Another finding consistent with this study's findings is the research finding [32] that students with higher KS self-efficacy contribute more to knowledge sharing activities than other students.

\subsection{Effect of knowledge sharing on student academic achievement}

Sharing knowledge appears to affect student academic achievement, according to research findings. It is critical to expanding student knowledge exchange activities to improve student academic performance in this environment. The study increased information sharing activities in numerous ways, including boosting student trust, improving student benevolence and increasing student knowledge sharing selfefficacy. The findings of this study corroborate those of several previous studies. According to research [30], knowledge sharing improves performance.

In contrast, the study's results [29] showed a significant correlation between social media use and academic achievement. Additionally, research data [5] imply that information sharing has a beneficial effect on students' academic achievement. Additional research findings that corroborate the abovementioned conclusions include those of studies[30] and [6].

\section{CONCLUSION AND RECOMMENDATION}

This study established that the variables trust, benevolence, and KS self-efficacy all had a beneficial effect on knowledge sharing. Additionally, this study showed that knowledge sharing has a beneficial impact on student's academic achievement. The findings of the research make both theoretical and practical contributions. The theoretical contribution is demonstrated by consolidating the link theory between these factors. Additionally, the results of this study have a practical application. Empirical evidence is presented to show how numerous variables, including trust, benevolence, and knowledge sharing selfefficacy, can increase knowledge sharing and student academic achievement. These studies make recommendations to parties interested in enhancing information exchange and students' academic achievement. This study model uses information sharing as a mediator between the variables of trust, benevolence, self-efficacy, and academic achievement. Future studies may explore moderating variables that improve or diminish the association between the three characteristics mentioned previously and student academic achievement. Thus, the model will more fully account for students' academic achievement. The subsequent study may also broaden the scope of the research goal to generate research outcomes.

\section{REFERENCES}

1. Michikyan, M., Subrahmanyam, K., and Dennis, J. Facebook use and academic performance among college students: A mixed-methods study with a multiethnic sample. Computers in Human Behavior, 45, 265-272. (2015).

2. Jones, N., Blackey, H., Fitzgibbon, K., and Chew, E. Get out of MySpace! Computers and Education, 54(3), 776-782. (2010).

3. Liang, Ting-Peng; Liu, Chih-Chung; and $\mathrm{Wu}$, Chia-Hsien. Can Social Exchange Theory Explain Individual Knowledge-Sharing Behavior? A Meta-Analysis. ICIS 2008 Proceedings. 171. (2008).

4. Bicen, H., and Uzunboylu, H. The Use of social 
networking sites in education: A case study of Facebook. Journal of Universal Computer Science, 19(5), 658-671. (2013).

5. 5 Sharabati, M. M. The Impact of Knowledge Sharing through Facebook on Students' Academic Performance in Palestine. The International Journal of Business and Information, 13(2), 155. (2017).

6. Shah, S. R., and Mahmood, K. Contributing factors in knowledge sharing for performance of university students in teachers' training programs. Library Management, 37(8-9), 496-506. (2016).

7. Zaqout, F., and Abbas, M. Towards a model for understanding the influence of the factors that stimulate university students' engagement and performance in knowledge sharing. Library Review, 61(5), 345-361. (2012).

8. Mayer, R. C., Davis, J. H., and Schoorman, F. D. An Integrative Model of Organizational Trust. The Academy of Management Review, 20 (3), 709-734. (1995)

9. Lee, M. R., Yen, D. C., and Hsiao, C. Y. Understanding the perceived community value of Facebook users. Computers in Human Behavior, 35(February), 350358. (2014).

10. Shapin, S. The House of Experiment in Seventeenth-Century England. Isis, 79(3), 373404. (1988).

11. Czerwinski, M.P. and Larson, K. Cognition and the web: moving from theory to web design, New Jersey: Lawrence Erlbaum Associates. (2002).

12. Hsu, C. L., and Lin, J. C. C. Acceptance of blog usage: The roles of technology acceptance, social influence and knowledge sharing motivation. Information and Management, 45(1), 65-74. (2008).

13. Olson, D. a, Liu, J., and Shultz, K. S. The influence of Facebook usage on perceptions of social support, personal efficacy, and life satisfaction. Journal of Organizational Psychology, 12, 133-145. (2012)

14. Kim, D. J., Ferrin, D. L., and Rao, H. R. A trustbased consumer decision-making model in electronic commerce: The role of trust, perceived risk, and their antecedents. Decision Support Systems, 44(2), 544-564. (2008).

15. Nahapiet, J. and Ghoshal, S. Social capital, intellectual capital and the organizational advantage. Academy of management review. 23(2), 242-266. (1998).

16. McLeod, C. Trust. The Stanford Encyclopedia of Philosophy. Stanford, CA: The Metaphysics Research Lab. (2008)

17. He, W., and Wei, K. K. What drives continued knowledge sharing? An investigation of knowledgecontribution and -seeking beliefs. Decision Support Systems, 46(4), 826-838. (2009).

18. Teh, P., Chong, C., Yong, C., and Yew, S. Internet self-efficacy, computer self-efficacy and cultural factors on knowledge sharing behavior. African Journal of Business Management, 4(18), 40864095. (2010).

19. Bock, G. W., and Kim, Y. G. Breaking the Myths of Rewards: An Exploratory Study of Attitudes about Knowledge Sharing. Information Resources Management Journal (IRMJ), 15(2), 14-21. (2002)

20. Kankanhalli, A., Tan, B. C. Y., and Wei, K.-K. Contributing knowledge to electronic knowledge repositories. An Empirical Investigation, 29(1), 113143. (2005)

21. Khumbula, C. and Kyobe, M. Investigating the extent to which students share tacit knowledge using mobile phones in group projects. Proceedings of the South African Institute of Computer Scientists and Information Technologists Conference on Knowledge, Innovation and Leadership in a Diverse, Multidisciplinary Environment, ACM, New York, NY, pp. 141-150. (2011)

22. Ross, C., Orr, E. S., Sisic, M., Arseneault, J. M., Simmering, M. G., and Orr, R. R.. Personality and motivations associated with Facebook use. Computers in Human Behavior, 25(2), 578-586. (2009)

23. Yu, A. Y., Tian, S. W., Vogel, D., and Chi-Wai Kwok, R. (2010). Can learning be virtually boosted? An investigation of online social networking impacts. Computers and Education, 55(4), 1494-1503.

24. Igbaria, M., and Tan, M. The consequences of information technology acceptance on subsequent individual performance. Information and Management, 32(3), 113-121. (1997).

25. Lin, C. P. To share or not to share: Modeling tacit knowledge sharing, its mediators and antecedents. Journal of Business Ethics, 70(4), 411-428. (2007).

26. Bock, G. W., Zmud, R. W., Kim, Y. G., and Lee, J. N. Behavioral intention formation in knowledge sharing: Examining the roles of extrinsic motivators, social-psychological forces, and organizational climate. MIS Quarterly: Management Information Systems, 29(1), 87111. (2005).

27. Van Den Hooff, B., and Ridder, J. A. Knowledge sharing in context: The influence of organizational commitment, communication climate and CMC use on knowledge sharing. Journal of Knowledge Management, 8(6), 117130. (2004).

28. Majid, S. and Wey, S. M. Knowledge sharing behavior of graduate students. Global Aspects and Cultural Perspectives on Knowledge Management: Emerging Dimensions, Information Science Reference, Hershey, PA, pp. 113-25. (2011).

29. Ainin, S., Naqshbandi, M. M., Moghavvemi, S., and Jaafar, N. I. Facebook usage, socialization and academic performance. Computers and Education (Vol. 83). (2015).

30. Du, R., Ai, S., and Ren, Y. Relationship between knowledge sharing and performance: A survey in 
Xi'an, China. Expert Systems with Applications, 32(1), 38-46. (2007).

31. Iris Reychav, and Jacob Weisberg. Good for Workers, Good for Companies: How Knowledge Sharing benefits Individual Employees. Knowledge and Process Management, 16(4), 186-197. (2009).
32. Rahab, and Wahyuni, P. Predicting Knowledge Sharing Intention Based on Theory of Reasoned Action Framework: An Empirical Study on Higher Education Institution. American International Journal of Contemporary Research, 3(1), 138-147. (2013). 